\title{
Analisis Variabel Sosial Ekonomi Terhadap Tingkat Inklusi Keuangan Negara Asia Tahun 2010-2015 Yana Raudhatul Jannah ${ }^{1}$ David Kaluge ${ }^{2}$
}

Fakultas Ekonomi dan Bisnis, Universitas Brawijaya yanaraudhatuljannah@gmail.com ${ }^{1}{ }_{\text {dkaluge@gmail.com }}^{2}$

DOI: https://doi.org/10.21107/dinar.v6i1.2532

\begin{abstract}
Abstrak
Program inklusi kenangan di Asia mulai gencar dilakukan dengan fokusnya yaitu meningkatkan akses masyarakat, terutama masyarakat yang belum menikmati jasa perbankan. Hal ini menjadikan inklusi keuangan sebagai salah satu satu fokus pembangunan di sektor keuangan diberbagai negara khususnya di kawasan Asia, karena sistem keuangan yang baik dapat mendorong pertumbuban ekonomi.

Penelitian ini bertujuan untuk melihat perbandingan tingkat inklusi keuangan dan melihat pengaruh variabel sosial ekonomi terbadap inklusi keuangan di negara Asia tabun 2010-2015. Untuk melihat perbandingan tingkat inklusi keuangan di beberapa negara Asia digunakan metode analisis Index of Financial Inclusion (IFI) yang dikembangkan oleh Sarma (2008), sedangkan untuk menguji bubungan antar variabel sosial ekonomi terhadap inklusi keuangan digunakan metode Ordinary Least Square (OLS) dengan teknik estimasi dalam pendekatan Fixed Effects Model.

Hasil dalam penelitian ini menunjukkan bahwa secara umum inklusi keuangan di beberapa negara Asia utamanya dipengarubi oleh dimensi keguanaan. Selain itu, hanya variabel GDP perkapita yang tidak signifikan berpengaruh secara parsial. Sedangkan variabel lainnya, yaitu, tingkat pengangguran dan jumlah penduduk di pedesaan mempunyai pengaruh yang signifikan terhadap indeks inklusi keuangan.
\end{abstract}

Kata Kunci: Inklusi keuangan, Index of Financial Inclusion. 


\section{Pendahuluan}

Pertumbuhan ekonomi dunia mengalami perlambatan pada beberapa tahun terakhir, di mana pertumbuhan ekonomi negara-negara berkembang yang mencakup 70\% pertumbuhan dunia menurun dalam lima tahun terakhir. Hal ini ditambah dengan perbaikan ekonomi di negara-negara maju. Harga komoditas energi yang rendah dan kebijakan moneter Amerika Serikat yang cukup ketat menjadi salah satu alasan perkembangan perekonomian global. Penyebab lainnya adalah Perlambatan dan rebalancing secara bertahap pada aktivitas perekonomian Cina (Deputi Bidang Ekonomi Kementrian PPN/Bappenas 2015).

Pertumbuhan perlambatan di Cina juga akan menekan pertumbuhan ekonomi di kawasan Asia berkembang yaitu Asia Tenggara dan India. Namun, jika dibandingkan dengan negara lain, tingkat PDB per kapita negara yang berada di kawasan Asia, memiliki nominal yang paling rendah dibandingkan dengan Amerika dan Eropa dengan tingkat rata-rata sebesar US\$1542.21 pada tahun 2015 .

\section{Gambar 1}

PDB per kapita negara Amerika Serikat, Kawasan Eropa dan Kawasan Asia tahun 2009-2015 (US\$)

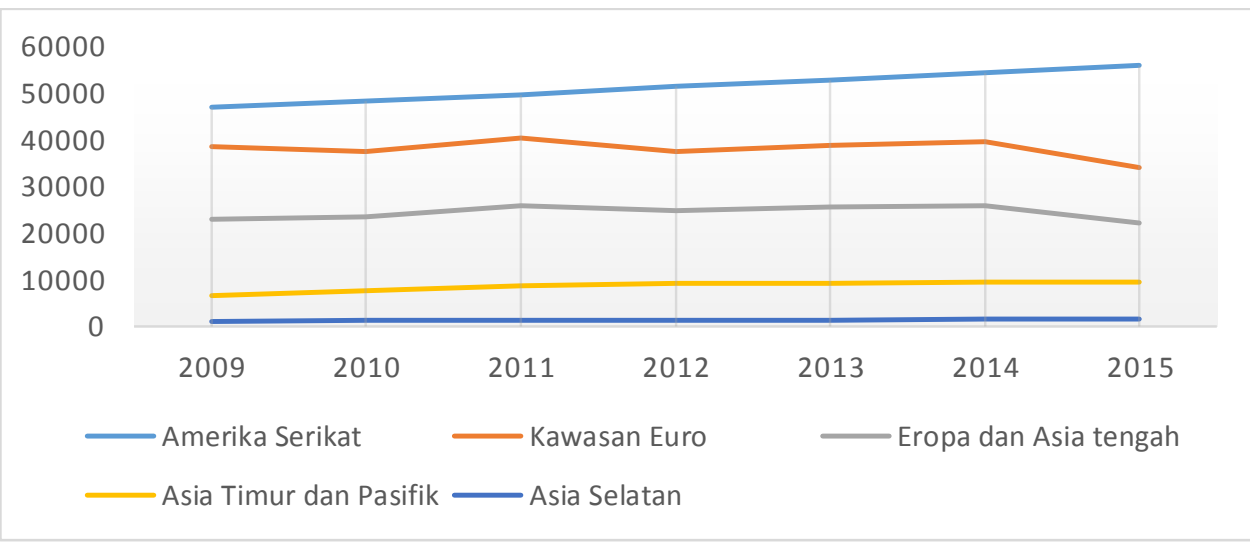

Sumber: World Bank, 2017 (diolah)

Hal ini didukung oleh data pada World Bank (gambar 1), menyebutkan bahwa negara-negara yang berada dikawasan Asia memiliki tingkat PDB per kapita paling rendah dibandingan pada kawasana Eropa dan Amerika. Selain karena aktivitas perekonomian Cina yang melambat, perlambatan pertumbuhan ini salah satunya disebabkan oleh kurangnya dukungan sektor keuangan baik perbankan maupun non-perbankan. Berdasarkan Data pada International Monetary Fund (IMF) menyebutkan bahwa, kurang dari 20\% masyarakat di negara Asia yang berpendapatan rendah memiliki akses di lembaga keuangan formal. Berbeda dengan Singapura, Jepang, dan Uni Emirat Arab yang lebih dari dua pertiga masyarakatnya memiliki akses terhadap jasa keuangan. Selain jumlah rekening, proporsi orang menabung lebih banyak dari jumlah proporsi orang meminjam kredit. 


\section{Gambar 2}

Akses terhadap Jasa Keuangan Negara di kawasan Asia tahun 2014

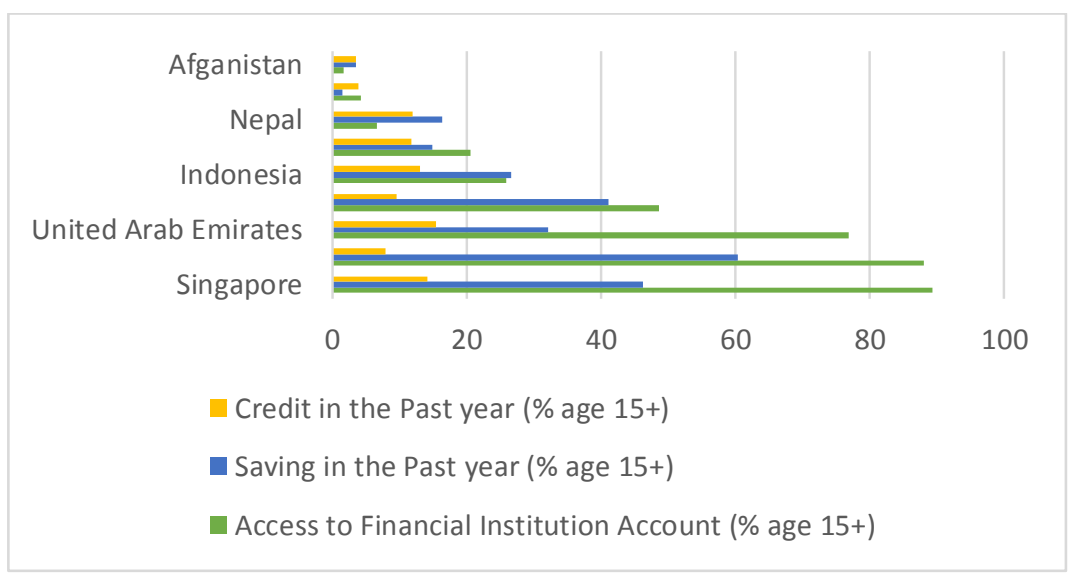

Sumber: International Monetary Fund, 2017 (diolah)

Menurut data pada gambar 2, beberapa masyarakat di negara Asia belum dapat menjangkau jasa keuangan formal, khususnya perbankan, disebut dengan unbankable people. Hal ini disebabkan karena banyak hambatan untuk mengaksesnya. Menurut Kunt (2008), pengetahuan masyarakat tentang fungsi lembaga keuangan dan ketidak sesuaian produk yang ditawarkan oleh lembaga keuangan dengan kebutuhan masyakat berpendapatan rendah menjadi salah satu penyebab dari hambatan tersebut (Dienillah and Anggraeni 2016). Selain itu hambatan juga berasal dari model bisnis bank itu sendiri, seperti posisi pasar, kondisi makroekonomi, tingkat kompetisi, serta peraturan yang dijalankan.

Untuk menghadapi hambatan-hambatan yang dihadapi maka perlu dilakukan peningkatan terhadap akses jasa keuangan melalui inklusi keuangan. Program inklusi keuangan di Asia mulai gencar dilakukan dengan fokus pada meningkatkan akses masyarakat, terutama masyarakat yang belum menikmati jasa perbankan. Ini menjadikan inklusi keuangan sebagai salah satu fokus pembangunan di sektor keuangan diberbagai negara khususnya negara yang berada di kawasan Asia, karena sistem keuangan yang baik dapat mendorong pertumbuhan ekonomi (Demirgüç-Kunt, Beck and Honohan 2008).

Paska krisis 2008 istilah inklusi keuangan menjadi tren terutama berasal dari dampak krisis kepada kelompok masyarakat in the bottom of the pyramid (masyarakat pinggiran berpendapatan rendah, tinggal di daerah terpencil yang mempunyai identitas illegal) yang umumnya unbankable yang tercatat sangat tinggi pada negara miskin dan berkembang (Bank Indonesia 2016). Menurut Reserve Bank of India, inklusi keuangan merupakan suatu proses dalam mengakses produk dan layanan keuangan yang tepat yang dibutuhkan oleh semua lapisan masyarakat khususnya kelompok masyarakat berpenghasilan rendah dengan biaya terjangkau yang diatur secara adil dan trasnparan. Definisi ini menekankan beberapa dimensi inklusi keuangan, yaitu aksesibiliyas, ketersediaan dan sistem kegunaan (Demirgüç-Kunt, Beck and Honohan 2008). Dimensi ini secara bersama-sama membangun sistem keuangan yang inklusif. 
Sistem keuangan merupakan inti dari proses pembangunan (Demirgüç-Kunt, Beck and Honohan 2008). Sehingga dengan adanya inklusi keuangan mampu memberikan banyak manfaat yang dapat dinikmati oleh masyarakat, regulator, pemerintah, dan pihak swasta. Beberapa manfaat yang akan didapat dengan adanya program inklusi keuangan antara lain, meningkatkan efisiensi ekonomi, mendukung stabilitas sistem keuangan, mendukung peningkatan Human Development Index (HDI), berkontribusi positif terhadap pertumbuhan ekonomi lokal dan nasional yang berkelanjutan, serta mengruangi kesenjangan sosial yang berdampak pada kesejahteraan masyarakat yang pada akhirnya berujung pada penurunan kemiskinan.

Menurut Sarma (2012) dalam penelitiannya IFI merupakan ukuran multidimensi yang dikembangkan sejalan dengan indeks pembangunan terkenal seperti IPM, HPI, GDI, dan GEM. IFI dapat digunakan untuk membandingkan tingkat inklusi keuangan di negara yang berbeda dan untuk memantau sejauh mana kemajuan ekonomi sehubungan dengan indeks inklusi keuangan dari waktu ke waktu. Selain itu, Sarma mencari determinasi indeks inklusi keuangan dengan indikator pembangunan ekonomi, seperti variabel sosial ekonomi, variabel infrastruktur, dan variabel perbankan. Sedangkan dalam penelitian Sanjaya dan Nursechafia (2015) menyebutkan bahwa inklusi keuangan di Indonesia utamanya dipengaruhi oleh dimensi aksesibilitas, serta dimensi lain seperti availibilitas dan penggunaan yang hanya memiliki proporsi yang cukup kecil, artinya kelompok masyarakat berpenghasilan rendah tidak sepenuhnya bisa mengakses jasa keuangan formal, khususnya dalam pengambilan kredit.

Mencermati penelitian-penelitian terdahulu yang ada dan beberapa fenomena yang telah dijelaskan membuat peneliti tertarik untuk meneliti lebih lanjut bagaimana perbandingan tingkat inklusi keuangan dan variabel sosial ekonomi yang berpengaruh terhadap inklusi keuangan negara yang berada di kawasan Asia. Selain itu, pada penelitian ini digunakan mengadopsi variabel sosial ekonomi dalam penelitian Sarma (2012) yang dilakukan di India.

\section{Metodologi Penelitian}

Jenis data yang digunakan adalah data panel, yaitu gabungan data cross section dan time series. Data panel tersebut berupa data cross section yang terdiri dari sembilan negara di kawasan Asia yang dibagi dalam tiga kategori yaitu Singapura, Jepang, dan Uni Emirat Arab sebagai negara bigh income; Cina, Indonesia, dan Filipina sebagai negara middle income; serta Nepal, Tajikistan, dan Afganistan sebagai negara low income. Data time series tahunan periode tahun 2010-2015. Data yang digunakan dalam penelitian ini merupakan data sekunder yang bersifat tahunan. Data-data ini dikumpulkan dari sumber seperti: World Bank, International Monetary Fund (IMF), Trading Economics, dan sumber data lainnya. Selanjutnya, untuk menunjang literatur serta pengetahuan, penulis menggunakan literatur rambahan yang didapat dari jurnal dan penelitian ilmiah lainnya. Penelitian ini dilakukan dengan bantuan software Microsoft Excel 2013 dan Eviews 9. 
Metode analisis yang dilakukan dalam penelitian ini adalah metode analisis deskriptif kuantitatif yaitu analisis Index of Financial Inclusion (IFI) yang dikembangkan oleh Sarma (2008), digunakan untuk mengukur tingkat inklusi keuangan di masing-masing negara dan metode Ordinary Least Square (OLS) dengan menggunakan teknik estimasi dengan pendekatan Fixed Effects Model akan digunakan untuk menguji hubungan antar variabel yang bersifat dependen dan memiliki beberapa varian (jenis) sehingga penulis bisa memiliki bentuk model yang paling sesuai dengan situasi yang dihadapinya. Terakhir, dengan teknik regresi penulis dapat melihat dampak perubahan nilai variabel-variabel independen terhadap variabel dependen. Oleh karena itu teknik regresi sangat membantu penulis yang membutuhkan alat untuk melakukan proyeksi (peramalan) (Prof. Gudono 2012).

\section{a. Index of Financial Inclusion (IFI)}

Menurut Sarma (2008) sistem keuangan inklusi dinilai dari tiga dimensi, pertama penetrasi perbankan yang digambarkan oleh jumlah rekening deposito di bank komersial per 1000 populasi dewasa. Kemudian ketersediaan jasa keuangan yang digambarkan oleh jumlah mesin ATM per 100000 populasi dewasa. Terakhir, kegunaan yang digambarkan proporsi kredit terhadap GDP. Sehingga untuk menghitung setiap dimensi digunakan rumus berikut:

$$
d_{i}=\frac{A_{i}-m_{i}}{M_{i}-m_{i}}
$$

Di mana:

$A_{i} \quad=$ nilai aktual dari dimensi i

$m_{i} \quad=$ nilai minimal dari dimensi $\mathrm{i}$

$M_{i} \quad=$ nilai maksimum dari dimensi i

Persamaan (1) menghasilkan nilai $0<d_{i}<1$, di mana semakin tinggi nilai $d_{i}$, maka semakin tinggi pula perolehan negara di dimensi i. Jika terdapat $n$ dimensi dari inklusi keuangan yang dihitung, maka perolehan suatu negara dari dimensi tersebut dipresentasikan dengan titik $\mathrm{X}=\left(d_{1}, d_{2}, d_{3}, \ldots, d_{n}\right)$ pada ruang $\mathrm{n}$-dimensi. Dalam ruang n-dimensi, titik $\mathrm{O}=(0,0,0, \ldots, 0)$ menunjukkan titik kondisi inklusi yang buru, sedangkan titik $\mathrm{I}=(1,1,1, \ldots, 1)$ menunjukkan kondisi yang ideal dalam setiap dimensi. Indeks inklusi keuangan, IFI, untuk negara pada tahun ke $i$ yang diukur dengan normalisasi terbalik Euclidean jarak pada titik D. Persamaannya adalah:

$$
I F I_{i}=1-\frac{\sqrt{\left(1-d_{1}\right)^{2}}+\left(1-d_{2}\right)^{2}+. .+\left(1-d_{n}\right)^{2}}{\sqrt{n}}
$$

Dalam persamaan (2), nilai IFI berada diantara 0 dan 1, jika diasumsikan seluruh dimensi memiliki bobot yang sama besar, maka masing-masing dimensi memiliki bobot sebesar 1, artinya dimensi memiliki peranan yang sama dalam menentukan tingkat inklusi keuangan. 
Dalam perhitungan IFI, dibutuhkan nilai tetap dari $\mathrm{M}_{\mathrm{i}}$ (batas atas) dan $\mathrm{m}_{\mathrm{i}}$ (batas bawah) untuk setiap dimensi. Agar dapat membandingkan IFI antar tahun pada tiap negara, maka batas atas maupun batas bawah harus dijadikan nilai tetap. Berikut ini merupakan data sebaran setiap dimensi yang disajikan dalam tabel 1 .

Tabel 1

Sebaran setiap Dimensi

\begin{tabular}{|l|c|c|c|c|c|}
\hline \multicolumn{1}{|c|}{ Dimensi } & $\begin{array}{c}\text { Jumlah } \\
\text { Observasi }\end{array}$ & Rataan & $\begin{array}{c}\text { Standar } \\
\text { Deviasi }\end{array}$ & $\begin{array}{c}\text { Minimu } \\
\text { m }\end{array}$ & Maximum \\
\hline $\begin{array}{l}\text { Penetrasi } \\
\text { perbankan }\end{array}$ & 54 & 13.99 & 9.36 & 2.21 & 34.14 \\
\hline $\begin{array}{l}\text { Ketersediaan } \\
\text { Jasa Perbankan }\end{array}$ & 54 & 42.91 & 37.88 & 0.55 & 130.83 \\
\hline Kegunaan & 54 & 81.36 & 83.5 & 3.76 & 318.6 \\
\hline
\end{tabular}

Sumber: data penelitian (2017)

Berdasarkan distribusi data di atas, penetrasi perbankan memiliki nilai maksimum sebesar 34.14, sehingga dibulatkan menjadi 34, artinya rata-rata setiap orang dewasa memiliki 34 rekening. Untuk jumlah mesin ATM, batas atasnya adalah 130.83, artinya dari 100.000 populasi dewasa dilayani oleh 131 mesin ATM. Terakhir adalah kegunaan, yaitu sebesar 318.6, artinya rata-rata deposito sebesar 319 persen terhadap GDP.

Berikut rangkuman dari seluruh dimensi yang digunakan dalam penelitian ini:

Tabel 2

\section{Dimensi dalam perhitungan IFI}

\begin{tabular}{|c|c|c|c|}
\hline Dimensi & Penetrasi Perbankan & $\begin{array}{c}\text { Ketersediaan } \\
\text { Jasa Perbankan }\end{array}$ & Kegunaan \\
\hline Indikator & $\begin{array}{c}\text { Jumlah rekening } \\
\text { deposito di bank } \\
\text { komersial (per } 1000 \\
\text { populasi dewasa) }\end{array}$ & $\begin{array}{c}\text { Jumlah mesin } \\
\text { ATM (per } \\
100000 \text { populasi } \\
\text { dewasa) }\end{array}$ & $\begin{array}{c}\text { Proporsi } \\
\text { kredit } \\
\text { terhadap } \\
\text { GDP }\end{array}$ \\
\hline Bobot $\left(\mathbf{w}_{\mathbf{i}}\right)$ & 1 & 1 & 1 \\
\hline Nilai Minimum $\left(\mathbf{m}_{\mathbf{i}}\right)$ & 2.21 & 0.55 & 3.76 \\
\hline Nilai Maksimum $\left.\mathbf{( M}_{\mathbf{i}}\right)$ & 34.14 & 130.83 & 318.6 \\
\hline
\end{tabular}

Sumber: data peneliti (2017)

\section{b. Model Regresi Ordinary Least Square (OLS)}

Langkah awal dalam estimasi data panel adalah perumusan model. Setelah merumuskan model yang akan digunakan, dilakukan pemilihan model pendekatan terbaik dengan menggunakan uji Chow dan uji Hausman. Selanjutnya dilakukan uji statistik (pengujian hipotesis individual (uji t), pengujian hipotesis berganda (uji f), dan uji koefisien determinasi (uji $\mathrm{R}^{2}$ )) dan uji ekonometrika (uji normalitas, uji multikolinearitas, uji autokolerasi, dan uji heteroskedastisitas) guna memenuhi uji asumsi klasik. 
Analisis determinan inklusi keuangan terhadap indicator sosial ekonomi pada negara-negara ASEAN, maka digunakan variabel dependen index of financial inclusion (IFI). Variabel independennya yaitu GDP perkapita, jumlah penduduk di atas 15 tahun, tingkat pengangguran, dan jumlah penduduk di pedesaan. Persamaan regresinya yaitu:

$$
I F I_{i t}=\beta_{0}+\beta_{1} \ln G D P_{i t}+\beta_{2} T P_{i t}+\beta_{3} J D_{i t}+\varepsilon_{i t}
$$

Di mana:

IFI $\quad$ : indeks inklusi keuangan negara $\mathrm{i}$ tahun ke $\mathrm{t}$

ln GDP $P_{i t} \quad$ : logaritma dari GDP per kapita negara $\mathrm{i}$ tahun ke $\mathrm{t}$

$T P_{i t} \quad$ : tingkat pengangguran negara $\mathrm{i}$ tahun ke $\mathrm{t}$

$J D_{i t} \quad$ : jumlah penduduk di pedesaan negara $\mathrm{i}$ tahun ke $\mathrm{t}$

$\beta_{0} \quad$ : konstanta

$\beta_{1}, \beta_{2}, \beta_{3} \quad$ : koefisien arah garis regresi

$\varepsilon_{i t} \quad:$ error term

\section{HASIL DAN PEMBAHASAN}

\section{Perbandingan Indeks Inklusi Keuangan antar negara}

Berikut ini ketiga dimensi dari indeks inklusi keuangan yang disajikan pada tabel 3.

Tabel 3

\section{Dimensi Pada Inklusi Keuangan}

\begin{tabular}{|l|r|r|r|r|r|r|r|}
\hline \multirow{2}{*}{ Stat. } & \multicolumn{7}{|c|}{ Tahun } \\
\cline { 2 - 7 } & 2010 & 2011 & 2012 & 2013 & 2014 & 2015 \\
\hline \multicolumn{7}{|c|}{ Indeks Penetrasi perbankan } \\
\hline Min & 0.00783 & 0.002505 & 0 & 0.004071 & 0.005951 & 0.001253 \\
\hline Max & 0.989039 & 0.991544 & 0.99311 & 0.99217 & 0.991857 & 1 \\
\hline Avg & 0.311167 & 0.364234 & 0.380242 & 0.386436 & 0.386575 & 0.385914 \\
\hline $\begin{array}{l}\text { St. } \\
\text { Dev }\end{array}$ & 0.301218 & 0.305809 & 0.305565 & 0.304183 & 0.303041 & 0.303265 \\
\hline \multicolumn{7}{|c|}{ Indeks Ketersediaan Jasa Perbankan } \\
\hline Min & 0 & 0.000691 & 0.000844 & 0.001382 & 0.001765 & 0.003147 \\
\hline Max & 1 & 0.981885 & 0.976819 & 0.980043 & 0.974056 & 0.975514 \\
\hline Avg & 0.277027 & 0.288336 & 0.324481 & 0.339082 & 0.356096 & 0.365955 \\
\hline $\begin{array}{l}\text { St. } \\
\text { Dev }\end{array}$ & 0.322766 & 0.314578 & 0.299302 & 0.296477 & 0.293393 & 0.293472 \\
\hline \multicolumn{7}{|c|}{ Indeks Kegunaan } \\
\hline Min & 0.023409 & 0.003017 & 0.000667 & 0.001207 & 0 & 0.000286 \\
\hline Max & 0.733706 & 0.812381 & 0.846239 & 0.936222 & 1 & 0.974304 \\
\hline Avg & 0.214105 & 0.225645 & 0.237465 & 0.259483 & 0.272036 & 0.270151 \\
\hline $\begin{array}{l}\text { St. } \\
\text { Dev }\end{array}$ & 0.227093 & 0.253834 & 0.265127 & 0.293967 & 0.313569 & 0.302789 \\
\hline \multicolumn{7}{|c|}{ Indeks Inklusi Keuangan } \\
\hline Min & 0.010365 & 0.002071 & 0.000504 & 0.002219 & 0.002569 & 0.001561 \\
\hline
\end{tabular}




\begin{tabular}{|l|r|r|r|r|r|r|}
\hline Max & 0.58458 & 0.589729 & 0.590552 & 0.597146 & 0.601703 & 0.604859 \\
\hline Avg & 0.243427 & 0.265818 & 0.285538 & 0.297029 & 0.304988 & 0.308151 \\
\hline $\begin{array}{l}\text { St. } \\
\text { Dev }\end{array}$ & 0.217642 & 0.213526 & 0.208229 & 0.20886 & 0.209691 & 0.208234 \\
\hline \multicolumn{7}{|c|}{ Sumber: data peneliti (2017) } \\
\hline
\end{tabular}

Tabel 3 menunjukkan statistik deskriptif IFI dengan tiga dimensi dari 9 negara Asia yang telah diestimasi. Hasilnya menunjukkan beberapa indikator seperti: minimum (Min), maksimum (Max), rata-rata (Mean), dan Standar Deviasi. Secara rata-rata, jumlah IFI beberapa negara Asia adalah 0.243427 pada tahun 2010 dan 0.308151 pada tahun 2015 . IFI cenderung berubah dengan fluktuasi kecil selama periode waktu tersebut.

Dari proporsi IFI tiga dimensi, dimensi kegunaan memiliki nilai yang paling tinggi, diikuti dengan ketersediaan jasa perbankan dan penetrasi perbankan. Hal ini mengindikasikan bahwa inklusi keuangan pada beberapa negara Asia ditentukan oleh dimensi kegunaan serta dimensi lain (ketersediaan jasa perbankan dan penetrasi perbankan) hanya memiliki proporsi yang lebih kecil. Salah satu kegunaan dari sistem keuangan oleh IMF diproporsikan dalam indikator proporsi kredit yang disalurkan terhadap GDP. Kredit/pinjaman ini digunakan oleh rumah tangga dan pengusaha. Menurut Sarma (2012) jasa-jasa keuangan seperti penyaluran kredit, tidak digunakan dengan baik, walaupun masyarakat memiliki akses terhadap jasa keuangan.

Pada dimensi penetrasi perbankan, proporsi orang dewasa miskin mencapai aksesibilitas yang tinggi pada sistem keuangan, namun mereka tidak menggunakan proporsi tersebut dengan baik karena adanya beberapa kendala, salah satunya berupa kantor cabang yang tidak dapat dijangkau dikarenakan tempat tinggal yang sangat terpencil sehingga mereka tidak bisa menjangkau akses tersebut. Proporsi populasi yang memiliki rekening bank merupakan sebuah ukuran dari penetrasi perbankan. Salah satu variabel yang digunakan adalah jumlah rekening deposito di bank komersial (per 1000 populasi dewasa). Jepang adalah negara yang memiliki tingkat penetrasi perbankan tertinggi dibandingkan negara Asia lainnya. Hal ini menunjukkan bahwa masyarakat di negara tersebut sedikit lebih banyak menggunakan akses perbanakan khususnya untuk penggunaan rekening di bank umum.

\section{Gambar 3}

\section{Rata-rata Jumlah Jumlah Rekening Depositu di Bank Komersial} (per 1000 populasi dewasa)

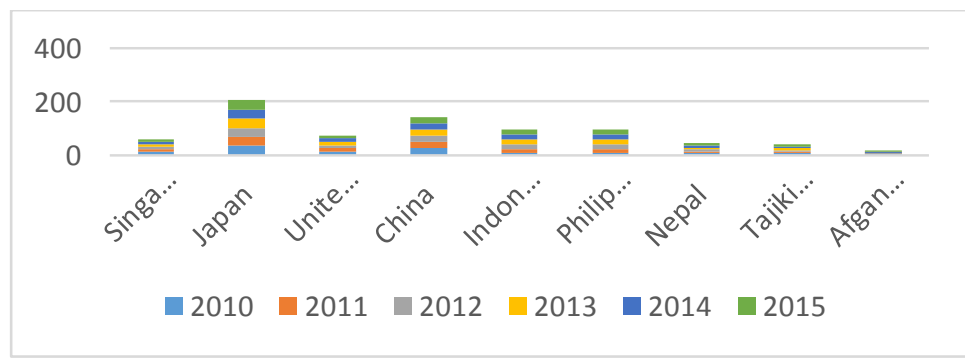

Sumber: The world bank (2016) 
Pada gambar 3, Jepang dan China merupakan dua negara yang memiliki tingkat penetrasi perbankan tertinggi dibandingkan 7 negara Asia lainnya. Jumlah rekening depositu di bank komersial untuk negara-negara tersebut cenderung konstan yaitu sekitar 40 per 100.000 orang dewasa di Jepang dan 23 per 100.000 orang dewasa di China. Hal ini menunjukkan masyarakat dikedua negara tersebut cukup mengenal sistem perbankan dengan terus melakukan perbaikan dalam pembangunan sektor perbankan khususnya untuk meningkatkan inklusi keuangan.

Selain penetrasi perbankan, dimensi lain dalam sistem inklusi keuangan adalah ketersediaan jasa perbankan. Dimensi ini mengukur sejauh mana kemudahan jasa perbankan dalam meberikan pelayanan kepada masyarakat. Variabel yang digunakan untuk mengukur dimensi ini adalah jumlah mesin ATM (per 100.000 populasi dewasa). Dalam dimensi ini, negara Jepang yang merupakan negara bigh income memiliki proporsi terbesar dalam pengadaan jumlah mesin ATM, sedangkan untuk negara middle income, China memiliki jumlah dan tren peningkatan terbesar dibandingkan negara middle income lainnya. Hal ini ditunjukkan oleh gambar 4.

\section{Gambar 4}

Rata-rata Jumlah mesin ATM (per 100000 populasi dewasa)

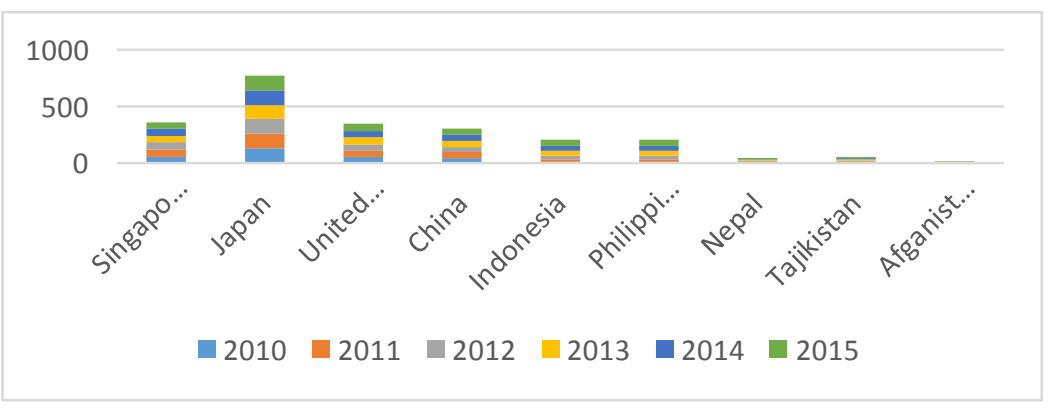

Sumber: The world bank (2016)

Untuk negara Asia ini, jumlah mesin ATM dari bank komersial di negara tersebut cenderung konstan dari tahun 2010-2015. Hal ini menunjukkan bahwa pembangunan fisik berupa mesin ATM yang merupakan akses dari sektor perbankan tidak lagi dilakukan. Hal ini juga mencerminkan terjadinya penurunan dalam perkembangan tekhnologi. Salah satu alternatif untuk mengganti jumlah mesin ATM dengan menggunakan sistem mobile banking dan internet banking. Sehingga dapat mengurangi biaya produksi dari suatu perbankan dan nasabah tidak perlu datang ke bank terdekat dalam melakukan transaksi perbankan.

Dimensi terakhir dari inklusi keuangan adalah kegunaan. Bank sebagai pihak intermediasi seharusnya memiliki manfaat bagi masyarakat. Salah satu bentuk intermediasi perbankan berupa penyaluran kredit. Dalam penelitian ini, kegunaan dilihat dari proporsi jumlah kredit/pinjaman oleh rumah tangga dan perusahaan terhadap GDP. Dalam gambar 5, China dan Singapura merupakan dua negara yang memiliki jumlah proporsi kredit terbesar dibandingan negara lainnya. Hal ini menunjukkan bahwa dengan semakin 
besar jumlah proporsi kredit yang disalurkan maka peningkatan GDP akan semakin besar dengan semakin meningkatnya jumlah konsumsi dari masyarakat.

\section{Gambar 5}

\section{Rata- rata Proporsi Kredit terhadap GDP}

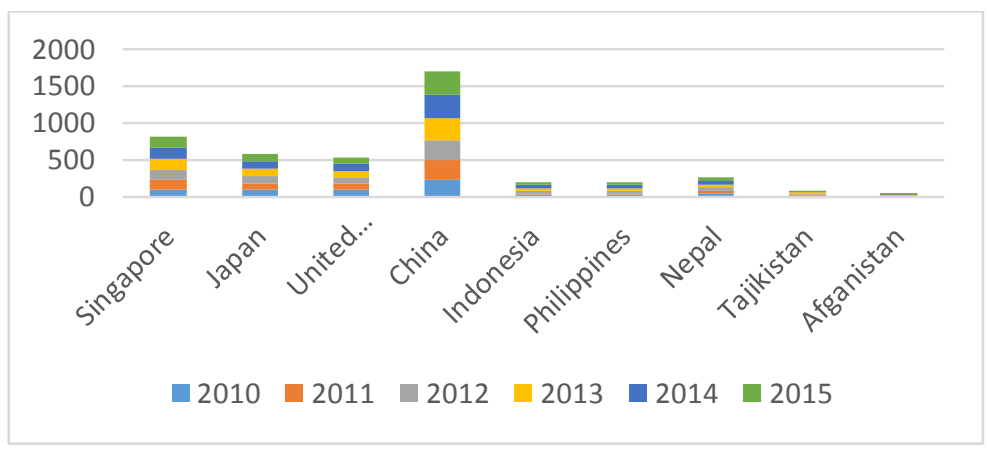

Sumber: The world bank (2016)

Gambar 3 menyajikan nilai IFI dari beberapa negara Asia tahun 2010-2015. Hasilnya menunjukkan bahwa negara ASEAN memiliki tren indeks inklusi keuangan yang meningkat. Pada periode terakhir, Jepang memiliki nilai indeks inklusi keuangan yang paling tinggi selama periode tersebut, yaitu sebesar 0,6, selanjutnya disusul oleh Kamboja $(0,59)$ dan Singapura $(0,37)$. Tingginya indeks inklusi keuangan di negara tersebut menunjukkan adanya kemudahan bagi masyarakat dalam mengakses jasa keuangan. Jasa perbankan telah dan sedang menjangkau mayoritas masyarakat, khususnya masyarakat berpenghasilan rendah. Jepang, China, dan Singapura sudah mampu menghilangkan hambatan-hambatan dalam akses jasa keuangan, sehingga masyarakat dapat memanfaat jasa-jasa yang diberikan oleh keuangan formal, khususnya jasa perbankan. Di mana, jasa perbankan yang diberikan telah sesuai dengan kebutuhan masyarakat yang ideal.

\section{Gambar 6}

Nilai IFI negara Asia tahun 2010-2015

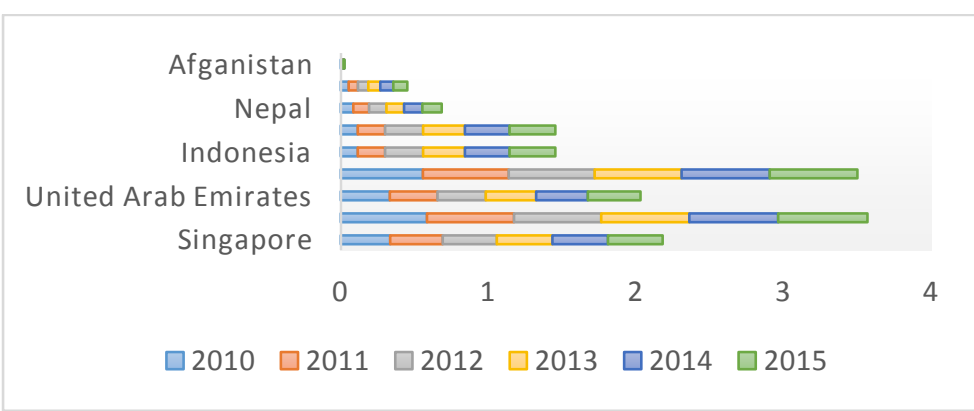

Sumber: data penelitian (2017)

Sedangkan negara dengan indeks inklusi keuangan terendah dengan nilai sebesar 0,001 adalah Afganistan. Rendahnya indeks inklusi keuangan di negara ini menunjukkan masih sulitnya akses terhadap jasa perbankan. Namun demikian, negara ini memiliki kecenderuangan dalam memperbaiki akses sektor perbankan secara annual. Perbaikan 
dalam usaha untuk menghilangkan hambatan askes jasa keuangan tersebut seperti, meningkatkan jumlah cabang bank khususnya untuk yang berada di wilayah pedesaan, pemberian kredit kepada UMKM, menambahkan produk-produk yang lebih sesuai dengan kebutuhan masyarakat pedesaan, dan lain sebagainya.

\section{Perbandingan Indeks Inklusi Keuangan antar Negara}

Perkembangan akses terhadap layanan jasa perbankan berbeda-beda disetiap negara. Pembangunan sektor terhadap jasa perbankan di negara maju lebih cepat dibandingkan dengan negara berkembang. Hal ini dapat dilihat dari indeks inklusi keuangan yang menunjukkan sejauh mana negara tersebut memberikan akses terhadap jasa perbankan kepada masyarakatnya. Pada tabel 4 menunjukkan Tingkat inklusi keuangan dari ketiga negara high income, yaitu Singapura, Jepang, dan Uni Emirat Arab cenderung konstan.

\section{Gambar 7}

Nilai IFI negara Jepang, Singapura, dan Uni Emirat Arab tahun 2010-2015

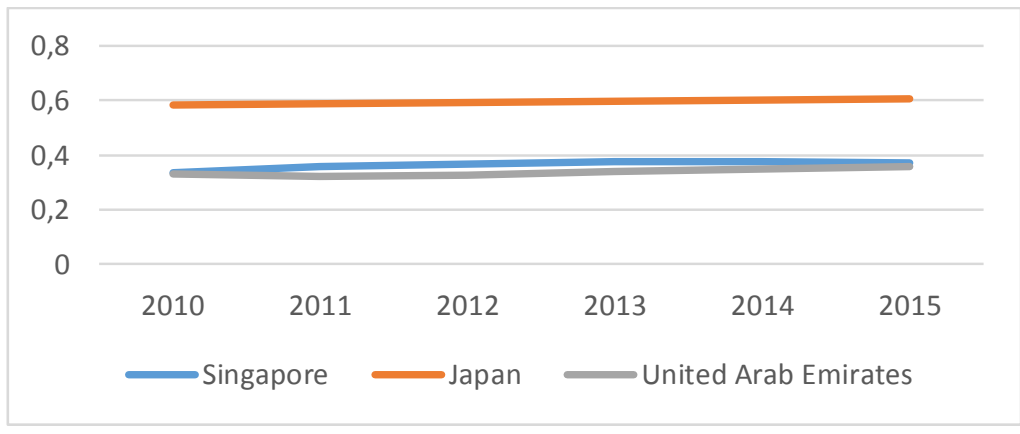

Sumber: data penelitian (2017)

Jepang merupakan negara high income yang tingkat inklusi keuangannya relatif tinggi dengan nilai indeks sebasar 0.6. Tingginya tingkat inklusi keuangan di Jepang dikarenakan tingginya nilai tiap-tiap dimensi dalam inklusi keuangan. Ketersediaan jasa perbankan yang dicerminkan dengan jumlah mesin ATM yang tersedia memiliki rata-rata 128 per 100.000 orang dewasa dari tahun 2010-2015. Jumlah ini paling tinggi dibandingkan negara lain yang diteliti. Namun, untuk dua negara high income lainnya yitu Singapura dan Uni Emirat Arab masih memiliki tingkat inklusi keuangan yang relatif rendah, masing-masing sebesar 0.37 untuk Singapura dan 0.35 untuk Uni Emirat Arab.

Tingginya nilai indeks inklusi keuangan di Jepang menunjukkan kemudahan bagi masyarakat dalam mengakses jasa keuangan, dimana jasa masyarakat telah menjangkau mayoritas masyarakat di negara tersebut. Hal ini menunjukkan bahwa Jepang cukup mampu menghilangkan hambatan-hambatan dalam akses jasa keuangan, sehingga masrakat dapat meningkatkan taraf hidupnya melalui pemanfaatan lembaga keuangan, khususnya jasa perbankan. Berdasarkan nilai indeksnya, inklusi keuangan di Jepang lebih inklusif dibandingkan dengan Singapura dan Uni Emirat Arab. Artinya, akses jasa keuangan di Jepang lebih mudah dibandingkan dengan Singapura dan Uni Emirat Arab. 


\section{Gambar 8}

Nilai IFI negara China, Indonesia, dan Filipina tahun 2010-2015

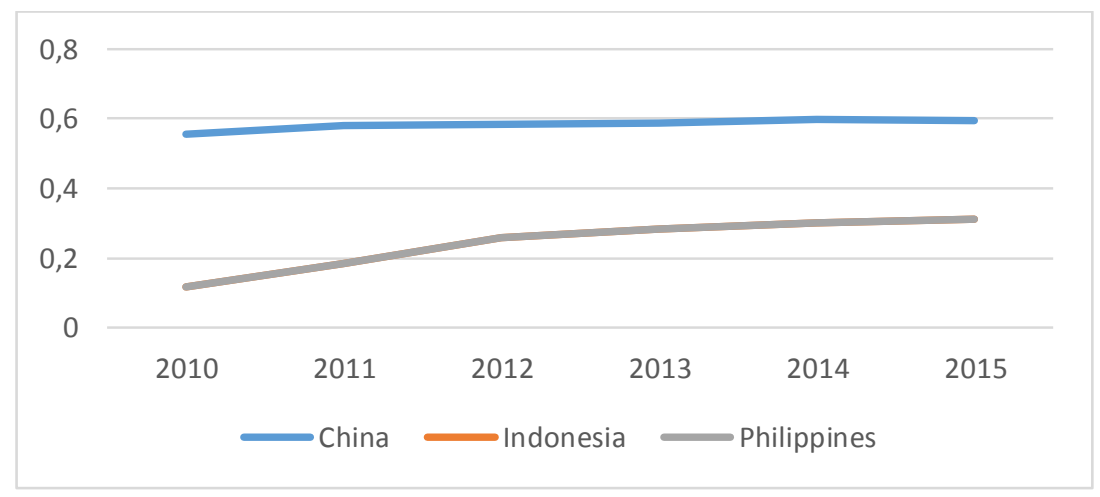

Sumber: data penelitian (2017)

Berbeda dengan negara high income, negara middle income seperti Cina, Indonesia, dan Filipina memiliki tren inklusi keuangan yang meningkat. Di mana negara Cina memiliki indeks inklusi keuangan terbesar, yaitu sebesar 0.59 tahun 2015. Hal dikarenakan, negara cina merupakan negara upper middle income. Sedangkan Indonesia dan Filipina merupakan negara lowe middle income. Meskipun negara middle income memiliki indeks inklusi keuangan di bawah negara high income, terdapat kecenderungan perbaikan dalam akses sektor perbankan setiap tahunnya. Usaha-usaha dalam menghilangkan hamabatan akses jasa keuangan seperti meningkatkan jumlah kantor cabang bank khususnya di wilayah pedesaan.

\section{Gambar 9}

Nilai IFI negara Nepal, Tajikistan, dan Afganistan tahun 2010-2015

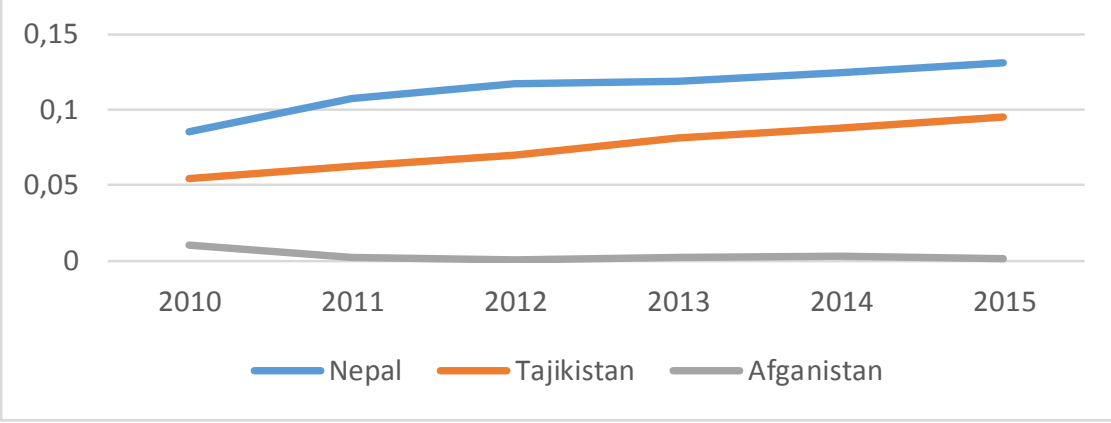

Sumber: data penelitian (2017)

Indeks inklusi keuangan di negara ow income seperti Nepal, Tajiskistan, dan Afganistan rata-rata memiliki tren peningkatan. Di mana negara Afganistan memiliki indeks terkecil dibandingkan kedua negara lainnya. Jumlah mesin ATM pada tahun 2015 kurang dari 1 per 100.000 orang dewasa. Berbeda dengan Jepang, di mana setiap 100.000 orang dewasa dapat mengakses 128 mesin ATM. Hal ini menunjukkan terdapat kesenjangan yang sangat besar antara Afganistan dengan Jepang, sehingga tingkat inklusi keuangan sangat jauh berbeda. 
Rendahnya indeks inklusi keuangan di Afganistan menunjukkan akses terhadap jasa keuangan sangat sulit. Sehingga masih terdapat banyak hambatan bagi masyarakat dalam mengakses jasa keuangan, khusus keuangan formal seperti perbankan. Selain karena jumlah kantor cabang yang masih minim, produk jasa perbankan yang ditawarkan masih rendah dan kurang sesuai dengan kebutuhan masyarakat di negara yang bersangkutan.

\section{Pengaruh Variabel Sosial Ekonomi terhadap Inklusi Keuangan}

Menurut Sarma (2012) ada beberapa indikator pembangunan yang memperngaruhi inklusi keuangan di suatu negara, yaitu seperti indikator variabel sosial ekonomi, variabel infrastruktur, dan variabel perbankan. Namun dalam penelitian ini indikator pembangunan yang dianalisis hanya dilihat dari variabel sosial ekonomi. Sehingga, untuk mengetahui pengaruh variabel sosial ekonomi terhadap indeks inklusi keuangan maka dilakukan estimasi dengan regresi data panel dengan hasil setimasi sebagai berikut:

\section{Tabel 4}

\section{Hasil Estimasi Regresi Data Panel}

\begin{tabular}{|c|c|c|c|c|}
\hline \multicolumn{5}{|c|}{ Coefficien } \\
\hline Variable & $\mathrm{t}$ & Std. Error & $\mathrm{t}$-Statistic & Prob. \\
\hline GDP & -0.475274 & 0.244439 & -1.944342 & 0.0586 \\
\hline $\mathrm{TP}$ & -0.211668 & 0.085949 & -2.462721 & 0.0180 \\
\hline JD & -0.120506 & 0.027513 & 4.379964 & 0.0001 \\
\hline $\mathrm{C}$ & -0.593623 & 2.762673 & -0.214873 & 0.8309 \\
\hline \multicolumn{5}{|c|}{ Effects Specification } \\
\hline \multicolumn{5}{|c|}{ Cross-section fixed (dummy variables) } \\
\hline R-squared & 0.783244 & & 0.445484 \\
\hline Adjusted R-squared & 0.778856 & \multicolumn{2}{|c|}{ S.D. dependent var } & 1.245956 \\
\hline S.E. of regression & 0.181176 & \multirow{2}{*}{\multicolumn{2}{|c|}{$\begin{array}{l}\text { Akaike info criterion } \\
\text { Schwarz criterion }\end{array}$}} & 0.385571 \\
\hline Sum squared resid & 1.378632 & & & 0.056426 \\
\hline Log likelihood & 22.41041 & \multirow{3}{*}{\multicolumn{2}{|c|}{$\begin{array}{l}\text { Hannan-Quinn criter. } \\
\text { Durbin-Watson stat }\end{array}$}} & 0.215110 \\
\hline F-statistic & 224.0531 & & & 2.823109 \\
\hline $\operatorname{Prob}($ F-statistic $)$ & 0.000000 & & & \\
\hline
\end{tabular}

Berdasarkan hasil estimasi pada tabel 4 dengan $\alpha$ sebesar 5\%, didapatkan bahwa variabel GDP perkapita dapat dipengaruhi secara tidak signifikan oleh indeks inklusi keuangan. Hal ini dapat dilihat dari koefisien GDP perkapita, di mana nilai koefisien sebesar 0.0586 di bawah nilai $\alpha$.

Tingkat pengangguran signifikan memengaruhi negatif terhadap indeks inklusi keuangan. Hal ini dapat dilihat dari koefisien jumlah penduduk di atas 15 tahun yang 
signifikan pada $\alpha$, yaitu dengan nilai koefisien sebesar 0.0180. Artinya, apabila tingkat pengangguran meningkat sebesar 1 persen, maka indeks inklusi keuangan akan menurun sebesar 0.211668. Jadi, tingkat pengangguran dapat menjelaskan kondisi inklusi keuangan pada negara Asia. Dimana, semakin tinggi jumlah penduduk pada negara Asia, semakin rendah tingkat inklusi keuangannya. Menurut Goodwin (2000) faktor yang dapat dikaitkan dengan inklusi keuangan adalah angkatan kerja. Pengangguran atau mereka yang memiliki pekerjaan tidak tetap dan tidak aman cenderung untuk berpartisipasi dalam sistem keuangan. Beberapa studi menemukan bahwa pembayaran upah melalui transfer tunai otomatis telah menjadi salah satu faktor utama yang mempengaruhi inklusi keuangan (Sarma and Pais, Financial Inclusion and Development: A Cross Country Analysis 2012). Selain itu, dengan banyanyaknya angkatan kerja yang bekerja di lapangan kerja sektor formal bisa menyiratkan partisipasi dalam sistem keuangan formal melalui penerimaan upah dan gaji dengan sistem transfer tunai tersebut. Dengan demikian proporsi tenga kerja sektor formal akan menjadi indikator penting dari tingkat inklusi keuangan. Sehingga, semakin kecil jumlah pengangguran, maka semakin besar peluang dalam mengakses jasa perbankan, hal ini akan meningkatkan tingkat inklusi keuangan pada negara Asia.

Jumlah penduduk di pedesaan signifikan memengaruhi negatif terhadap indeks inklusi keuangan. Hal ini dapat dilihat dari koefisien jumlah penduduk di atas 15 tahun yang signifikan pada $\alpha$, yaitu dengan nilai koefisien sebesar 0.0001. Artinya, apabila jumlah penduduk di pedesaan meningkat sebesar 1 persen, maka indeks inklusi keuangan akan menurun sebesar 0.120506. Jadi, jumlah penduduk di pedesaan dapat menjelaskan kondisi inklusi keuangan pada negara Asia. Dimana, semakin tinggi jumlah penduduk pada negara Asia, semakin tinggi pula tingkat inklusi keuangannya. Menurut Leyshon (1995), masyarakat pedesaan memiliki kecenderungan kecil dalam mengakses jasa keuangan. Kebanyakan daerah pedesaan merupakan daerah dengan infrastruktur yang buruk, menyebabkan sulitnya dalam menyediakan jasa keuangan. Jika akses keuangan terjangkau, hal ini akan menimbulkan biaya transaksi yang cuku besar bagi penyedia jasa keuangan, sehingga penyedia jasa keuangan sulit dalam merencanakan dan membuka akses keuangannya di pedesaan. Selain besarnya biaya transaksi, produk-prduk yang ditawarkan oleh jasa keuangan pun tidak sesuai dengan kebutuhan masyarakat pedesaan. Dengan demikian, semakin sedikitnya jumlah masyarakat di pedesaan, maka akses jasa keuangan semakin mudah, sehingga meningatkan tingkat inklusi keuangan.

Pada tabel 4 dapat diketahui pula koefisien determinasi $\left(\mathrm{R}^{2}\right)$ sebesar 0.783244 atau sebesar 78\%. Ini berarti bahwa kontribusi dari variabel GDP perkapita, tingkat pengangguran, dan jumlah penduduk di pedesaan dapat menjelaskan pengaruhnya terhadap variabel indeks inklusi keuangan sebesar 78\%. Sedangkan sisanya yaitu sebesar $22 \%$ dijelaskan oleh variabel lain diluar persamaan regresi pada penelitian ini.

Uji F statistik digunakan untuk menguji hipotesis pengaruh simultan dari variabel independen terhadap variabel dependen. Berdasarkan hasil didapatkan F hitung sebesar 
224.0531, dengan Sig F (0,000) yang lebih kecil dari 5\% $(0,05)$ menunjukkan bahwa $\mathrm{H}_{1}$ diterima dan $\mathrm{H}_{0}$ ditolak yang berarti bahwa variabel variabel GDP perkapita, tingkat pengangguran, dan jumlah penduduk di pedesaan secara bersama sama mempunyai pengaruh yang signifikan terhadap variabel indeks inklusi keuangan.

\section{Kesimpulan}

Penelitian ini mencoba untuk menjadi alat penting bagi pengambil kebijakan untuk menggunakannnya sebagai perbandingan dan motivasi untuk semakin menganut prinsip inklusif dalam keuangan. Artikel ini memberikan paling tidak dua kesimpulan, pertama, perbandingan indeks inklusi keuangan di beberapa negara Asia dengan menggunakan dimensi penetrasi perbankan ketersediaan jasa perbankan, dan kegunaan. Hasilnya menunjukkan bahwa secara umum inklusi keuangan di negara Asia utamanya dipengaruhi oleh dimensi keguanaan. Salah satu kegunaan dari sistem keuangan oleh IMF diproporsikan dalam indikator proporsi kredit yang disalurkan terhadap GDP. Kredit/pinjaman ini digunakan oleh rumah tangga dan pengusaha. Jasa-jasa keuangan seperti penyaluran kredit, tidak digunakan dengan baik, walaupun masyarakat memiliki akses terhadap jasa keuangan.

Kedua, melihat pengaruh indikator pembangunan berupa variabel sosial ekonomi terhadap indeks inklusi keuangan di beberapa negara Asia pada periode 2010-2015. Dapat disimpulkan bahwa hanya variabel GDP perkapita yang tidak signifikan berpengaruh secara parsial. Sedangkan variabel lainnya, yaitu tingkat pengangguran dan jumlah penduduk di pedesaan mempunyai pengaruh yang signifikan terhadap indeks inklusi keuangan. Selanjutnya, dapat diketahui bahwa dari ketiga variabel bebas tersebut yang paling dominan pengaruhnya terhadap indeks inklusi keuangan adalah jumlah penduduk di pedesaan karena memiliki nilai koefisien paling besar.

Mengacu pada kesimpulan di atas, beberapa implikasi dan saran yang dapat diberikan, pertama bagi negara Asia, peningkatan inklusi keuangan harus diikuti oleh penurunan hambatan dalam mengakses layanan jasa-jasa keuangan formal serta menambah produk perbankan yang lebih sesuai khususunya dengan masyarakat berpendapatan rendah. Misalnya kredit mikro untuk usaha kecil dan menengah dan menambah outlet perbankan yang menjangkau pedesaan. Selain itu, perlu dilakukan sosialisasi kepada masyarakat terkait dengan pentingnya inklusi keuangan, dengan demikian masyarakat akan merasa bahwa jasa keuangan sangat penting dan dekat dalam jangkauannya.

\section{Daftar Pustaka}

Bank Indonesia. 2016. Keuangan Inklusi. Accessed Desember 17, 2016. http://www.bi.go.id/id/perbankan/keuanganinklusif/Indonesia/Contents/Default.aspx.

Demirgüç-Kunt, Asl1, Thorsten Beck, and Patrick Honohan. 2008. Finance for all? Policies and Piffalls in Expanding Access. The International Bank for Reconstruction and Development, Washington DC: The World Bank. 
Deputi Bidang Ekonomi Kementrian PPN/Bappenas . 2015. Perkembangan Ekonomi Indonesia dan Dunia. Laporan Triwulan IV tahun 2015, Jakarta: Deputi Bidang Ekonomi Bappenas.

Dienillah, Azka Azifah, and Lukytawati Anggraeni. 2016. "Dampak Inklusi Keuangan Terhadap Stabilitas Sistem Keuangan di Asia." Buletin Ekonomi Moneter dan Perbankan Volume 18, Nomor 4.

Goodwin, D., L. Adelman, S. Middleton, and K. Ashworth. 2000. "Debt, Money Management and Access to Financial Services: Evidence from the 1999 PSE Survey of Britain." 1999 PSE Survey Working Paper 8, Centre for Research in Social Policy (Loughborough University).

International Monetary Fund. 2016. IMF Finance. International Monetary Fund. http://www.imf.org/external/index.htm.

Kasmir. 2004. Dasar-dasar Perbankan. Jakarta: Pt. Raja Grafindo Persada.

Leyshon, A., and Thrift N. 1995. "Geographies of Financial Exclusion: Financial Abandonment in Britain and the United States." Transactions of the Institute of British Geographers .

Organisation for Economic Co-operation and Development. 2015. The OECD Economic Outlook. Economic Outlook, OECD Development Centre. http://www.oecd.org/.

Prof. Gudono, Ph.D., CMA. 2012. Analisis Data Multivariat. Yogyakarta: BPFE.

Sanjaya, I Made, and Nursechafia. 2015. "INKLUSI KEUANGAN DAN PERTUMBUHAN INKLUSIF: ANALISIS ANTAR PROVINSI DI INDONESIA." Buletin Ekonomi Moneter dan Perbankan, Volume 18, Nomor 3.

Sarma, Mandira. 2008. "Index of Financial Inclusion." Indian Council for Research on International Economic Relations.

Sarma, Mandira, and Jesim Pais. 2012. "Financial Inclusion and Development: A Cross Country Analysis ." Indian Council for Research on International Economic Relations.

The World Bank. 2016. World Bank Open Data. Accessed Desember 15, 2016. http://data.worldbank.org/.

Trading Economics. 2016. Loans to Bank. Accessed Desember 15, 2016. www.tradingeconomics.com. 